\title{
Paradoxes of Autonomy and Exceptionalism in Molière and Madame de Lafayette
}

\section{Larry W. Riggs}

\section{(2) OpenEdition \\ 1 Journals}

\section{Electronic version}

URL: http://journals.openedition.org/studifrancesi/10112

DOI: 10.4000/studifrancesi. 10112

ISSN: 2421-5856

\section{Publisher}

Rosenberg \& Sellier

\section{Printed version}

Date of publication: 1 December 2017

Number of pages: 441-452

ISSN: 0039-2944

\section{Electronic reference}

Larry W. Riggs, "Paradoxes of Autonomy and Exceptionalism in Molière and Madame de Lafayette",

Studi Francesi [Online], 183 (LXI | III) | 2017, Online since 01 December 2018, connection on 22 January 2021. URL: http://journals.openedition.org/studifrancesi/10112 ; DOI: https://doi.org/10.4000/

studifrancesi. 10112

\section{(c) (i) (9)}

Studi Francesi è distribuita con Licenza Creative Commons Attribuzione - Non commerciale - Non opere derivate 4.0 Internazionale. 


\title{
Paradoxes of Autonomy and Exceptionalism in Molière and Madame de Lafayette
}

\begin{abstract}
The seventeenth century, in Europe, saw the rise of modern individualism: of the myth that humanity is composed of autonomous, competitive self-seekers who belong to society only in order to moderate the effects of their "natural" rapacity. Simultaneously, the modern epistemology that posits a detached, rational subject, acquiring definitive knowledge in order to manipulate a passive world of objects, arose and developed. This is the individual whom Stephen Greenblatt famously called «self-fashioning». There are repressed paradoxes at the heart of this synthesis of the autonomous individual and the transcendent subject: the competitive individualist is motivated by self-interested desire, but the dominant modern conception of rationality requires a subject capable of transcending desire and the body, and competitive selfinterest can be pursued only in the social context. The attempted radical separation of subjectivity from the body is, according to David Le Breton, an artifact of early modern Europe. Recent research in linguistics, cognitive science, and evolutionary psychology undermines these myths of autonomy and objectivity, emphasizing the entanglement of the mind with emotions, the body, and the social group. The article finds these "new" insights anticipated by Molière and Madame de Lafayette, whose works dramatize both the ambitions of the emerging individualists and the paradoxes inherent in those ambitions. Molière mocks a gallery of would-be autonomous subjects trying to escape reciprocity, emotion, and the body. In La Princesse de Clèves, Madame de Lafayette delves equally deeply into the tensions that arise when ambition inspires delusions of exceptionality.
\end{abstract}

\section{The Myths of the Autonomous Individual and the Transcendent Subject}

The seventeenth century, in France and elsewhere in Europe, saw the rise of modern individualism: of the myth that humanity is composed of autonomous, competitive self-seekers who belong to society only in order to moderate the effects of their "natural" rapacity. There are many commentators who locate the advent of this myth of the autonomous, self-maximizing individual squarely in the early modern period. Simultaneously, and complementarily, the modern epistemology that posits a detached, rational subject, acquiring definitive knowledge in order to manipulate a passive world of objects, arose and developed. This is the individual whom Stephen Greenblatt famously called «self-fashioning» ${ }^{1}$.

The early modern atrophy of corporate entities that, for centuries, had provided individuals with both identity and constraint, was a factor here, as was the destabilization of a dominant worldview by discoveries that were incompatible with it. The modern, detached, autonomous subject of supposedly certain knowledge arose from a situation of epistemological confusion. At the same time, the seeming emergence of the individual from dense webs of corporate relationships encouraged claims of 
freedom from mutual obligations, but also led to a craving for recognition. Where, after all, could a completely autonomous, and therefore perfectly isolated, individual's sense of identity possibly come from? Thus, opportunity and anxiety characterized this historical moment. Certainty was sought as an antidote to intense insecurity. Greenblatt's self-fashioning individual was in anguish; he/she could «self-fashion» only in competition with and at the expense of others. And yet, however fashioned, the self required confirmation, which could obviously come only from the group.

There are clearly repressed paradoxes at the heart of this synthesis of the autonomous individual and the transcendent subject: the competitive, atomized individualist is motivated by self-interested desire, but the dominant modern conception of rationality requires a subject capable of transcending desire and the body, and competitive self-interest can be pursued only in the social context. The attempted radical separation of subjectivity from the body is, according to David Le Breton, an artifact of early modern Europe ${ }^{2}$. It is worth noting in passing that Theophrastus, who was extremely influential in seventeenth-century France, argues that desires and emotions have their origin in corporeal motions.

The myth of objectivity, which underpins the dominant modern epistemology, depends on just this denial of emotional, bodily, and social influences on perception and knowledge. Also paradoxically, attempts to repress or control emotion cause hypertrophy of the repressed emotion. Jeremy Rifkin argues that Freud and other early psychologists perpetuated the modern conception of man as an individualist selfmaximizer, which itself inadvertently - subconsciously? - perpetuated the medieval idea of physical man as fallen ${ }^{3}$. There is no place for empathy in this worldview, and no place for the acceptance of vulnerability and of the need for others that Alasdair MacIntyre sees as vital to morally significant living. MacIntyre contends that our vulnerabilities and afflictions are essential to our self-knowledge and rationality ${ }^{4}$. The autonomous, exceptional individual is a fiction; the self is the sum of its bodily, emotional, and relational history. "Self-knowledge" always depends on our experience of social interactions. As Theophrastus would have it, life is ruled more by fortune than by wisdom or morality.

This paradoxical situation led to the development of what J.P. Singh-Uberoi sees as two minds, or two kinds of mind, in Europe 5 . On the one hand, for example, Michel de Montaigne, in his Réflexions sur la maladie and other essays, emphasized the impact of the dispositions and conditions of the body and the emotions on the operations of reason. On the other hand, René Descartes sought to escape the "trap" of the body and the emotions by fantasizing a mind capable of certainty because it was separate from them. Descartes's English contemporary, Sir Francis Bacon, argued that dispassionately dissecting nature to expose its secrets would give humanity the power to construct a new world which would dependably serve human purposes. In the seventeenth century, Western European culture would be divided between those who, like Montaigne, could accept - who even preferred - ambiguity and ambivalence, and those who wanted to believe that they could transcend uncertainty and all

(2) D. Le Breton, Anthropologie du corps et modernité, Paris, Presses Universitaires de France, 2000, p. 62.

(3) J. Rifkin, The Empathic Civilization: The Path to Global Consciousness in a World in Crisis, New York, Tarcher/Penguin, 2009, p. 45.

(4) A. MacIntyre, Dependent Rational Animals: Why Human Beings Need the Virtues, Chicago, Open Court, 1999, p. 1.

(5) J.P. Singh-Uberoi, The Other Mind of Europe: Goethe as a Scientist, Delhi, Bombay University Press, 1984, p. 28. 
other existential limits. The seventeenth-century political philosopher, Thomas Hobbes, epitomized the specifically political paradox inherent in the individualist myth: Hobbes's view of humans as inherently autonomous, fiercely competitive individuals led him to posit overwhelming State power as a necessary constraint. The "autonomy" of rapacious individuals therefore justified the absolute power of Leviathan.

\section{Recent Research Undermines the Myths}

Much recent research in linguistics, cognitive science, and evolutionary psychology undermines these myths of autonomy and objectivity by consistently emphasizing the inextricable entanglement of the mind with emotions, the body, and the social group. Primatologist Frans De Waal argues that, particularly in the modern period, we have been obsessed with what seems to place us "above" the animals, and that we have therefore committed ourselves to denial and repression ${ }^{6}$. In elucidating significant continuities between human behavior and that of other primates, De Waal shows the primacy of affect and the falsity of the emotion/reason duality ${ }^{7}$. We are situated not only in the body and the emotions, but also in the group. Relationship precedes individuality and is more fundamental ${ }^{8}$. Reason and emotion constantly interact ${ }^{9}$. The very ambition to be autonomous, to be an exception to this involvement in the body and in the group, makes sense only in a social context. Who would acknowledge the autonomy and the exceptionality of an individual? The desire for autonomous individuality is hardly exceptional if we believe that everybody feels it and is motivated by it.

The self is thus always existentially situated; sociality, empathy, and reciprocity are more fundamental than individuality in human behavior. Neuroscientist Antonio Damasio, in a study aptly called Descartes's Error, says that there is no pure reason, that the body and emotions serve to structure and motivate thought $t^{10}$. Linguists George Lakoff and Mark Johnson argue that all thought depends on sensory perception, bodily movement, and physical situation ${ }^{11}$. According to Lakoff and Johnson, we can communicate, at all, only because of the commonalities of our bodily experience $^{12}$. Reason and language are thus locally situated bodily functions. Like Damasio, De Waal criticizes Descartes and debunks the claims of "pure" reason and the myth of the separate, independent, competitive individual who accepts social life only to ease strife ${ }^{13}$. Society and reciprocity are foundational, not derivative or "voluntary". Moreover, evolutionary biologist Edward O. Wilson argues that, in modernity, pressures on individuals intensify as roles become more numerous and the number of

(6) F. DE WAAL, The Age of Empathy: Nature's Lessons for a Kinder Society, New York, Crown / Random House, 2010, p. 15.

(7) F. De WAaL, Primates and Philosophers: How Morality Evolved, Princeton, NJ, Princeton University Press, 2009, p. 6.

(8) J. RifKIN, op. cit., p. 28.

(9) Ibid., pp. 146-47.

(10) A. DAMASIO, Descartes's Error: Emotion, Reason, and the Human Brain, New York, Penguin, 1994, p. 248

(11) G. Lakoff and M. Johnson, Philosophy in the Flesh: The Embodied Mind and Its Challenges to Western Thought, New York, Basic Books, 1999, p. 4.

(12) Ibid., p. 151.

(13) F. DE WaA, Empathy cit., p. 20. 
roles that each must play increases. The problem of the self arises from this multiplicity $^{14}$. As an ideology, individualism is the anxious response to a sense of disintegration. Empathy and exchange are required to resolve moral dilemmas and to support individual identity. However, mutually beneficial exchange is incompatible with the desire to be radically autonomous and exceptional. Rifkin argues that understanding comes not from detached analysis, but from empathic communion ${ }^{15}$. All of these scholars emphasize that dependence and vulnerability are central to human experience. Detachment from the body and the emotions is as illusory as is independence of others.

\section{Molière and Madame de Lafayette Had Already Undermined the Myths}

I find that these contemporary insights are anticipated by a number of early modern French writers whose works dramatize both the ambitions of the emerging individualists and the paradoxes inherent in those ambitions. I will look closely at two of these writers here. Among the most trenchant critics of individualist delusions is Molière, who mocks a gallery of would-be autonomous subjects trying to escape reciprocity, emotion, and the body. His comic types reflect what James F. Gaines recently termed «an age of Absolutism that was trying to free itself from the contingencies of ordinary life» ${ }^{16}$. Molière's ridicules wish, and claim, to be exceptions, to be above and beyond existential limits. In La Princesse de Clèves, Madame de Lafayette delves equally deeply into the tensions that arise when ambition inspires delusions of exceptionality. We will see that the Princesse's mother's ambition to make her an exceptional, and therefore an exceptionally desirable, object condemns the Princesse to sacrifice her own desire to a wholly sterile isolation from the society wherein exceptionality must be sought, but cannot be achieved. These authors' treatment of the desire to be exceptional powerfully illuminates a central paradox that I have mentioned: the ambition to be an exception can be expressed only in a social context, and the status of exception would be meaningful only if recognized and acknowledged by others. This ineluctable reality undermines pretensions of autonomy and seals the individual's entanglement in a network of exchanges. The "autonomous" individual, liberated from constraining corporate entities, required and justified overwhelming State power to control him; the isolated individual, bereft of the support of corporate entities, wandered and raged, or whimpered, in search of identity.

\section{Paradoxes of Autonomy and Transcendence in Molière}

Molière's relentless comic deconstruction of efforts to gain absolute control and comprehensive knowledge directly challenges the belief that definitive truth can be found, and thereby undermines the claim that knowledge can buttress or justify any kind of authoritarianism. As we have seen, the desire for transcendence, and transcendent power, requires suppression of emotion and of the body. Comic theatre foregrounds the body, with all of its desire, clumsiness, and vulnerability. It constantly

(14) E.O. Wilson, On Human Nature, Cambridge, MA, Harvard University Press, 2004, p. 95.

(15) J. RiFKIN, op. cit., p. 154.

(16) J. Gaines, Molière and Paradox: Skepticism and Theater in the Early Modern Age, Tübingen, Narr

Verlag, 2010, «Biblio 17», p. 47. 
reminds us of the contingent and the relationa ${ }^{17}$. Comedy is thus inherently hostile to delusions of autonomy and transcendence. Molière shows that it is ridiculous to pretend to be a disembodied mind, or an autonomously self-fashioning individual, when all can see one's desiring, performing, vulnerable body. Georges Forestier makes the useful related point that, in the seventeenth-century French context, Molière, himself, would have hesitated to claim originality, or autonomy, for himself as author ${ }^{18}$. Michael Call devotes an extremely interesting new book to exploring the complex network of contingencies that conditioned authorship, itself, for Molière and his contemporaries. In the plays, as Call demonstrates, delusions of autonomy and epistemological control are often linked to the question of authority, or authorship ${ }^{19}$.

Molière's comic absolutists are actually engaged in trying to create a world to which their version of Truth would be adequate. They want to force the world, including other people, into a form to which their version of truth is appropriate, and which they can completely dominate. In a recent article on Molière's Le Bourgeois gentilhomme, Ralph Albanese elucidates the dramatist's critique of the illusion that knowledge can fulfill the desire for self-transformation and control ${ }^{20}$. This reflects the times: in what Michel de Certeau called the age of representations ${ }^{21}$ and Philip Sherrard termed the epoch of abstraction ${ }^{22}$, maps, mathematical models, and other representations were imposed on, and then substituted for, the real, natural world. Knowledge was expected to confer enormous manipulative power. There was, in the emerging epistemology, a strong preference for willed constructs over the given world. However, such constructs are motivated conceptions; they seem to confirm delusions of "autonomy", but their origin in desires will out.

From Arnolphe, in L'École des femmes, to Argan, in Le Malade imaginaire, Molière's comic types seek transcendence by denying feelings and mortifying bodies, their own and others'. In Molière's ceuvre, there is, in fact, a kind of progression through the plays to Argan's attempt to cheat death. Argan encounters the truth about his life only when he pretends to be dead. All of Molière's major characters can be seen as hopelessly naïve, and desperately hungry, avatars of the Cartesian subject, supposedly separate from and independent of the "objects" of knowledge and manipulation. The desire to manipulate is, paradoxically, the very definition of entanglement.

Molière critics often argue that one or another of the plays is "archetypal". It seems to me that, at best, this depends entirely on which aspect of the plays one is focusing on. For my purposes, here, I will say that it is illuminating to begin by looking at Le Misanthrope. Despite, or, rather, because of, his wish for radical separateness, the main character, Alceste, is involved in a social network. He wants to be distinguished - as he says, in verse 63 , «Je veux qu'on me distingue» ${ }^{23}$ - to be an exception. The very grammar of this sentence implicitly acknowledges that distinction is both

(17) L. Riggs, Molière and Modernity: Absent Mothers and Masculine Births, Chalottesville, VA, Rookwood Press, 2005, p. 205.

(18) G. Forestier, Le Théâtre dans le théâtre, Genève, Droz, 1996, p. 70.

(19) M. Call, The Would-Be Author: Moliere and the Comedy of Print, West Lafayette, IN, Purdue University Press, 2015.

(20) R. Albanese, La Dialectique savoir/ignorance dans "Le Bourgeois gentilhomme", forthcoming in Le Nouveau moliériste.

(21) M. De Certeau, Heterologies: Discourse on the Other, trans. B. Massumi, Minneapolis, University of Minnesota, 1986, p. 180.

(22) P. SHERRARD, The Rape of Man and Nature: An Enquiry into the Origins and Consequences of Modern Science, Ipswich, UK, Golgonooza Press, 1987, p. 49.

(23) Molière, Euvres Complètes, Paris, Editions du Seuil and The Macmillan Company, 1962, p. 324. 
an object of desire and something that can only be conferred by others; it would be a social construct. Again, the desire to be recognized as exceptional is the essence of dependence.

Alceste, whom Gaines calls an «absolute nominalist» ${ }^{24}$, wants all words to have a clear meaning whose stability confirms his own. In one of his many felicitous phrases, Gaines characterizes Alceste's quest as a «Cartesian nostalgia for simple knowledge» ${ }^{25}$. Alceste tries to ignore the fact that real communication is a network of exchanges in which interlocutors influence and interpret and sometimes deceive each other. The play dramatizes the consequences of Alceste's refusal to accept the necessity - and the responsibility - of interpretation; he refuses to think of communication as contingent reciprocal exchange.

Alceste's insistence that others be sincere is, in fact, a desire for knowledge and control. He wants others to be transparent to him and to recognize his uniqueness, but, paradoxically, what the play shows is his resemblance to them. In fact, all of the characters are alike in their quest for recognition and distinction, but they can offer each other only involvement in a motivated exchange of contingent communication. In any case, exchanges of recognition must be recognizable, and thus they cannot be unique; if they were truly unique, they could not be deciphered. Gérard Defaux goes so far as to see in Le Misanthrope an auto-critique by Molière, a recognition that his authorial stance as critic of character flaws in others is untenable $e^{26}$.

Paradoxically, then, language meeting Alceste's standard would not be communication; it would be meaningless. He could never be recognized as completely distinct. Michael Hawcroft points out the contradiction inherent in the fact that Alceste wants his departure from society to be spectacular ${ }^{27}$. His egotism must have an audience. Moreover, Alceste's demand that others be perfectly sincere is a futile absolutist attempt to escape the realities of ordinary life. His need reflects early modernity's increasingly nervous concern with sincerity. Rifkin plausibly attributes this anxiety to the fact that individual identity was no longer dependably defined by group affilia$\operatorname{tion}^{28}$. Alceste is surrounded by atomized individuals who, like himself, are competing for distinction. The "world" of Célimène's household is a microcosmic dramatization of the one implied by the modern myth of individualism.

In Tartuffe, the Impostor's dupe, Orgon, is another living paradox, in that his desire for control makes him easy to manipulate. Like Molière's other comic types, Orgon ignores motives, especially his own and those of his seducer. Despite describing Tartuffe, in verse 272, as «un homme», Orgon does not consider that having motives, or desires, is part of the definition of a man. Orgon must ignore motives, for the usual molièresque reason: he wants his own motives to be the environment in which others must live. He wants his desire to be, literally, their world. This brings us to yet another of the playwright's deepest paradoxes: the desire to absorb all into the self, to make of the self a world, does not eliminate vulnerability; it greatly increases it. Orgon's pseudo-ascetic rejection of love for his family, and of emotion in general, does not make him exceptional or powerful; it makes him typical of would-be selffashioners with delusions of grandeur. Paradoxically, it also allows Tartuffe's desire to displace and replace Orgon's, just as Tartuffe takes possession of his dupe's house.

(24) J. GAINES, op. cit., p. 79.

(25) Ibid., p. 89.

(26) G. DEFAuX, Molière, ou les métamorphoses du comique: de la comédie morale au triomphe de la folie, Lexington, KY, 1980, «French Forum», pp. 527 ff.

(27) M. Hawcroft, Molière: Reasoning with Fools, Oxford, Oxford University Press, 2007, p. 170.

(28) J. RifKIN, op. cit., p. 274. 
Arnolphe, in L'École des femmes, is another character who wants to construct a dominant, invulnerable self. Arnolphe has always seemed to me to be an obvious parody of Descartes, foolishly convinced that his special knowledge, and the méthode by which he applies it, will enable him to transcend the bodily, emotional world of risk and uncertainty - of doubt. Arnolphe's attempt to prove that his method for avoiding cuckoldry is foolproof, because it is based on his "knowledge" of what causes cuckoldry, will be undermined by the existential reality of feelings, including his own. Hawcroft argues that the play's comic effects are based on the incongruity between Arnolphe's confidence in his plan and its utter failure to work ${ }^{29}$. Not only does the plan not work, it is itself the very means by which Arnolphe's fate is realized. Paradoxically, but inevitably, Arnolphe's enclosure of his ward, Agnès, in a prison of isolation and ignorance will make her vulnerable to her very first experience of reciprocal romantic communication. Arnolphe's denial of his own love - of his desire for emotional exchange with Agnès - deprives him of empathy, and thus makes him hopelessly ignorant of the realities of human interaction. The play dramatizes the fundamental need for authentic exchange and the fact that, because of this need, there can be no manipulation of others from a safely detached position.

Here, at the beginning of modernity's long infatuation with "objectivity", Molière establishes what might be called a Heisenberg Principle of human relations: the self is inextricably implicated in every social exchange. Desire seals involvement. From the play's opening debate about cuckoldry, we can see that Arnolphe is so stupefied by his "knowledge" and his method that he does not know that his own behavior will make it less likely that Agnès will love him and be faithful. Arnolphe desperately denies the fact that thought cannot precede or control experienced reality, and the method he trusts to overcome contingency is, paradoxically and appropriately, the means by which his desire is frustrated and his fear is realized.

In L'Avare, Harpagon certainly rejects both risk and exchange, hoarding his wealth as a means of gaining absolute control over his family, and even of escaping the natural succession of generations. The most significant paradoxes in this play are that Harpagon's strategy of starving his household intensifies everyone's appetites, thereby increasing resistance to his vigilance, and that his "enjoyment" of his wealth takes the form of fear that it will be stolen. Here, Molière revisits a paradox first sketched in L'École des femmes: the value of property, including a wife regarded as property, as in Arnolphe's case, depends on the belief that others covet it, or her. The very value of the individual's possessions is, then, dependent on others' supposed desire for them. One must fear theft or cuckoldry in order to value one's wealth or one's wife. Possession equals paranoia, and only acceptance of risk and of the other's independent subjectivity can make a healthy reciprocal relationship possible. Harpagon's regime of mortification, and his substituting money for other values, install insatiable hunger at the heart of his world. The desire for money is by definition a hypertrophic desire; it can never be satisfied, because it is an abstract appetite. Money is an unsatisfying substitute for more concrete, more natural, and less controllable objects of desire.

Yet another instance of pseudo-asceticism, and of supposedly special knowledge used to consolidate power, is Les Femmes savantes. Philaminte and her transcendentalist disciples are, paradoxically, enslaved by their ambition to the hack poet and pseudo-philosopher, Trissotin. Their desire for absolute authority makes them as subservient to this mountebank as Orgon is to Tartuffe. A principal paradox here 
lies in the learned ladies' attempt to parlay abstractionist language into a form of transcendence that will give them absolute cultural power.

The grounding of the ladies' metaphors, and of their desire for power, in earthly - and earthy - reality constantly reminds us that transcendence is a rhetorical illusion. Molière thus anticipates a central point of Lakoff and Johnson's work: our thinking is inescapably metaphorical, and metaphors derive their meaning from their physical terms, or roots ${ }^{30}$. Molière also anticipates here, with brilliant linguistic irony, Wilson't contention that even our "highest" cultural achievements depend completely on our biological nature ${ }^{31}$. The savantes' transcendentalist rhetoric, made as it is of metaphors, thus mocks their ambition to be above the common condition. Trissotin is an avatar of Tartuffe, and the learned ladies are, like Orgon, dupes of their own ambition. Their pretensions make them mere breeding stock, or copying machines, for the propagation of abstractionist language. Their denial of their own desires makes them creatures of Trissotin's wants. Like Orgon, they allow themselves to be inhabited by another's very concrete desire. In this play, Molière denounces knowledge and authority claiming to be both above the physical world and universally valid, just as he lampooned, in Tartuffe, similar claims for the language of dévotion. There are no exceptions to the earthbound human condition; believing that there can be such exceptions opens the deluded to displacement by purveyors of false transcendence.

In Le Malade imaginaire, Argan's version of the delusional lust for transcendence is focused explicitly on manipulation of his body. Argan is determined to be the ultimate exception: he wants to transcend bodily degeneration and death. Constant counting seems to serve Argan's illusory transcendence, to flatter his desire for abstraction from the body. Gaines may have revealed that this play provides Molière's most incisive critique of modernity's epistemological ambition and arrogance. Ever the master of historical context, Gaines reminds us that the early modern coincidence of the birth of pharmaceutics and the raging scourge of syphilis in Europe generated a shattering medical paradox: the short-term "cure" of the pox with mercury usually led to death, in the longer term ${ }^{32}$. Moreover, not only is Argan undoubtedly weakened by his numerous cures and enslaved and exploited by their purveyors, but his desire to transcend the body, and to avoid its death, keeps his nose firmly planted in the smell of his body's effluvia. The desire to transcend and control the body leads to an exaggerated attachment to it. Molière's embodiment of Argan, as he himself struggled with what would be a truly fatal illness, is a paradox that escapes the theatre to invade real life.

In Amphitryon, not even a god can be exceptional. In this play, not only the self's delusions of transcendence, but also the illusion of having a stable identity, at all, are deconstructed. In fact, even the divine Jupiter is able to have his way with Alcmène only by pretending to be her husband, Amphitryon. Call follows Max Vernet in asserting that this play is quintessentially theatrical: it dramatizes the dramatic, showing the paradoxical coexistence of stability and mutability at the core of the self ${ }^{33}$. Jupiter cannot derive any unadulterated satisfaction from his conquest, since it is not really "He" who conquers. His divine power cannot enable him to escape the contingencies of human life. Even a god must become a desiring, performing actor in order to enter

(30) G. LAKOFF and M. JoHnSON, op. cit., p. 210.

(31) E.O. Wilson, In Search of Nature, Washington, D.C., Shearwater, 1996, p. 100.

(32) J. GAINES, op. cit., pp. 130-131.

(33) M. Vernet, Molière: Côté jardin, côté cour, Paris, A.-G. Nizet, 1991, p. 114. Call, pp. 8-9. 
into a relationship with a human being. The ultimate existential futility of delusions of power could not be more effectively evoked.

\section{Paradoxes of Virtue and Exceptionality in "La Princesse de Clèves"}

I have always been tempted to read the final words of La Princesse de Clèves - «et sa vie, qui fut assez courte, laissa des exemples de vertu inimitables $\rangle^{34}-$ as an ironical comment on the sterility and inhumanity of Mademoiselle de Chartres's/Madame de Clèves's fate. Is the ending a surprise, or is it the completion of a destiny set in motion by the Princesse's mother's determination to make her daughter exceptional? Is that exceptionalism itself a trap? Pierre Force explicitly compares the Princesse to the Molière characters whose fundamental error is regarding themselves as exceptions to some general rule about humanity ${ }^{35}$. I see Molière's critique of exceptionalism in broader terms, and I believe that Madame de Lafayette shared the comedian's view. In a sense, there are no general rules about humanity, other than the fact that every individual must seek identity and pursue purposes within a society and within the constraints defined by the body and the emotions. As I argued in looking at Molière's plays, the desire for distinction and control makes sense only within the social context, and therefore makes the would-be exception the creature of his or her social partners. It is a matter for reciprocal exchange. Society pressures all of its members to resemble one another, if only insofar as they are all competing for the recognition that only they, as a group, can confer.

Does the Princesse de Clèves ultimately opt out of courtly society because she feels the pull of this logic of convergence? Is distinction or exceptionality whose price is flight to a desert - an excellent reason for considering Le Misantbrope and La Princesse de Clèves in the same essay - meaningless? Does the Princesse's retirement from the Court represent the attainment of a relative independence, or is it the ultimate triumph of patriarchal repression, the ultimate infantilization of a woman? In the seventeenth-century context, is there really anything truly exceptional about withdrawing - for a part of each year - to a convent? The ending is implicit in the beginning, since the Princesse has been taught by her mother that to resemble other women is to be disgraced, but the consequences of her mother's ambition have made that resemblance inevitable.

Of what use, in fact, are inimitable examples? The novel's final sentence seems to me to be quintessentially paradoxical. Does the heroine attain transcendence of disorder and anxiety, achieving a state like the précieux ideal of high status through indefinite suspension, or does the process begun by her mother's pedagogy consign her to a sterile space of repression essentially like the one constructed for Agnès by the paranoiac Arnolphe, in L'Ecole des femmes? Is her withdrawal to be understood as a positive assertion of an independent identity, or is it the culmination of a process whereby a false and impossible identity has been imposed on her? Madame de Chartres has taught her daughter that virtue requires «une extrême defiance de soimême» ${ }^{36}$, that the virtuous self is divided against itself.

In my reading, the situation wherein Madame de Clèves is forced to live has much in common with what all of Molière's tyrannical, patriarchal buffoons threaten

(34) Madame De Lafayette, Romans et Nouvelles, Paris, Garnier Frères, 1961, p. 395.

(35) P. Force, Molière ou le prix des choses: morale, économie et comédie, Paris, Editions Nathan, 1994 , pp. 49-50.

(36) Ibid., p. 248. 
to impose on the young women whom they seek to control. Madame de Chartres acts as an agent of patriarchy, forcing her daughter to internalize the paradoxical imperative to be exceptionally virtuous, while maximizing her desirability within the regime of exchanges that rules her society.

Ursula A. Kelly, in focusing particularly on the early modern and modern education of young women, argues that schooling or pedagogy is a «mode of social control», designed to produce particular forms of subjectivity and to elicit certain kinds of participation in social life $e^{37}$. Education, most effectively deployed in the form of stories, constructs desire, forming subjectivities who substitute for "natural" objects of desire those that it is convenient for the social order to provide. Kelly shows that stories serve as means of forming socially acceptable, self-disciplining subjects, and are thus fundamental to systems of social control. Madame de Chartres's moralistic pedagogy illustrates Kelly's point admirably: she uses tendentious stories to teach her daughter to make virtue the principal object of her desire ${ }^{38}$.

As I have argued, this pedagogy places Mademoiselle de Chartres in a paradoxical situation. Since it is designed to enhance her value in the marketplace of marriage, it requires that she be, ultimately, conventional, not exceptional. Her value must be recognizable. It also requires her to identify virtue with self-distrust. Insofar as virtue is an object of desire for her, her "desire" is in conflict with her desire. As Kelly would put it, education has formed the Princesse to desire what amounts to a socially valuable version of herself. She has internalized the contradictory imperatives of her social milieu and of her mother's pedagogy.

The stories of "fallen" women that form the core of Madame de Chartres's moralistic teaching resemble the tales of women's nefarious influence during the Fronde that Domna Stanton refers to in her The Fiction of "Préciosité" and the Fear of Women" ${ }^{39}$. This supports my suggestion that Madame de Chartres has designed her daughter to be a valuable commodity within the patriarchal order, indeed, to serve as a support for that order. Her pedagogy, in other words, actually makes it impossible for her daughter to be truly exceptional. Mademoiselle de Chartres is formed by the sort of stories that Stanton associates with the cultural and political castration of women. The Princesse, thanks to her mother's loyalty to patriarchy, can "virtuously" desire only to repress her own desire.

Paradoxically, then, Madame de Chartres' ambition, which expresses itself in her ambition to make her daughter exceptional, creates the circumstances that threaten to make her typical, to make of her a character in another cautionary tale. There are, in fact, several dimensions of paradox in the novel. First of all, in order to enhance her daughter's value in the competitive marketplace of aristocratic marriage, Madame de Chartres educates her in isolation from the Court. She shelters her. Then, she throws her to the wolves. Moreover, this protection, combined with the inculcation of devotion to virtue, makes Mademoiselle de Chartres more appetizing. Thirdly, as she adds to her daughter's value on the market, Madame de Chartres also increases her vulnerability while also making her more relentlessly pursued. Mademoiselle de Chartres is in a situation analogous to that of Agnès: having no experience of erotic exchange, she risks being seduced by its first appearance in her life.

(37) U. Kelly, Schooling Desire: Literacy, Cultural Politics, and Pedagogy, London, Routledge, 1997, p. 1.

(38) Ibid., p. 248.

(39) D. Stanton, The Fiction of "Préciosite" and the Fear of Women, «Yale French Studies» 62, 1981, pp. 107-134. 
In making what I believe is a closely related point, Jane Marie Todd refers to Michel Foucault's contention that the modern subject, characterized by introspection and self-criticism, is formed by internalizing power ${ }^{40}$. Internalizing her mother's powerful lessons has linked the Princesse's pride inextricably to her self-distrust, to exercising what little power she has against herself. Her very sense of self contains a paradox, a contradiction. Here again, we have something very much like what Arnolphe tries to impose on Agnès: he wants Agnès literally to internalize the strictures of the maximes du marriage - «Imprimez-le-vous-bien», he commands, in verse $678^{41}$ - in order to make it integral to her subjectivity. Madame de Chartres's lessons similarly make up the fund of negative examples which amount to internalized proscriptions for her daughter.

The Princesse has internalized the paradox of virtue. In fact, virtue is a paradox. What, in fact, makes virtue valuable? As a form of ornamentation, giving éclat and élévation ${ }^{42}$ to a woman, virtue works to intensify the very desire it is supposed to protect against. It is comparable to the jewels that Mademoiselle de Chartres is selecting when Monsieur de Clèves first sees her. Virtue is, ultimately, the most appetizing of the decorative attributes that draw the predatory male gaze. It thus increases the power of that which it is supposed to resist. Virtue is also a prize and a prospective guarantee in a context defined by pervasive infidelity and dangerous male rivalry. If a virtuous woman is "won", her value immediately decreases. Virtue as an appetizer for males is, therefore, incompatible with any form of consummated love; and yet, its value also depends on the belief that the woman may be accessible. For the Princesse, the degree to which she can aspire to be exceptional is the degree to which she is desired. Thus, her education, in forming her to desire virtue, has formed her to desire to be desired, but also to desire to repress her own desire. She must be an extremely desirable object within the conventional economy of courtly relations. Her attractiveness must be displayed in sufficiently conventional form to be recognized. And yet, she must desire only to live the paradox.

Still another dimension of paradox is that Madame de Chartres's ambition and pride - she is «extrêmement glorieuse» ${ }^{43}$ - lead her to place her daughter in the very circumstances that will maximize the difficulty of her remaining virtuous. Once she is married to a man whom she does not love, Madame de Clèves is in precisely the situation for which her education has not prepared her, except by making her fearful of the male desire she has been formed to attract, and by putting her at odds with her own desires. In fact, does not virtue, as Madame de Lafayette has elucidated it for us, imply the woman's internalizing male desire, male rivalry, and male jealousy as the objects of her desire, as well as of her fear? She must desire to be desired in order to demonstrate her capacity to resist, and that resistance will make her more desirable.

Again, we encounter the paradox of distinction, or of exceptionalism. Madame de Chartres intends to make her daughter a creature whose superior virtue and value - whose status of exception - will be recognized by all. However, subjecting her daughter to the pressures of the Court, and, most of all, marrying her to a man she does not love, make it inevitable that she will become typical. Is it, in fact, possible for a society to perceive value in what truly lies outside its lexicon of generalizations, its

(40) J. TodD, The Power of Confession: The Ideology of Love in "La Princesse de Clèves", in P. Henry, An Inimitable Example: The Case for The "Princesse de Clèves", Washington, D.C., The Catholic University of America Press, 1992, pp. 225-234.

(41) MOLIĖRE, op. cit., p. 185.

(42) Ivi, p. 248.

(43) Ibid.. 
fund of recognized values? To the extent that Madame de Chartres has brought an unusually desirable young woman to Court, she has made her the object of the men's desire to distinguish themselves by possessing her. Paradoxically, like all competition, this generalized rivalry has a leveling effect. As is the case in Le Misanthrope, the characters resemble one another in their thirst for distinction. In my reading of the novel, this leads to the most persuasive interpretation of Madame de Lafayette's prodigal use of superlatives: like the final sentence, it is ironical. At Court, there is nothing more typical than pretensions to exceptionality. If everyone is superlative, then no one is exceptional. Nothing could be more typical at Court than Madame de Chartres's pride and ambition. How could we expect her daughter, who is the instrument of that pride and ambition, to sustain her exceptionality?

I have argued that virtue in the novel has meaning and value only as a quality that both awakens and resists male desire, and that thereby both assuages and exacerbates male fear of and aggression toward rivals. Moreover, a woman must want to be desired by more than one man if she wants to be known as virtuous. The issue of what her own desire might be focused on, other than the reputation for virtue that depends on others and whets male appetites, cannot arise. Madame de Clèves's marriage to a man she does not love can only intensify her need for that which is condemned and excluded by the essentially patriarchal moral curriculum that has shaped her. Internalizing her mother's powerful lessons, which are rendered irresistible by Madame de Chartres's brilliantly manipulative management of her own death, has linked her daughter's pride inextricably to her self-distrust. The Princesse's fate is definitively sealed by her husband's death, a death caused by the male's jealousy and fear of a rival, a jealousy and fear that were inherent in and necessary to her mother's attempt to make her exceptional, in the first place.

\section{Conclusion}

Molière and Madame de Lafayette, along with a number of other early modern writers, question the emerging myth of the autonomous, self-fashioning individual. I hope I have argued persuasively that they anticipate the findings of cutting-edge linguistics, evolutionary psychology, and cognitive science by showing the primacy of involvement and exchange. Is exceptionalism a rejection of vulnerability, fallibility, dependence, and mortality? Is it, rather than merely an attempt to escape the reach of a particular generalization, a desire to transcend the fundamental contingencies of human life? 